\title{
Reconstruction of the relative sea-level (RSL) of the Gulf of Dvina (White Sea) based on the study of lake sediments on the Onega Peninsula
}

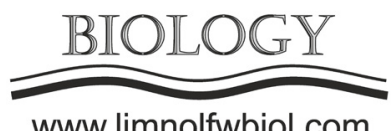

www.limnolfwbiol.com

\author{
Kublitskiy Y.A. ${ }^{1 *}$, Repkina T.Y. ${ }^{2}$, Leontiev P.A. ${ }^{1}$, Zaretskaya N.E. ${ }^{3}$, \\ Peretrukhina A.O. ${ }^{1}$, Shilova O.S. ${ }^{2}$, Subetto D.A. ${ }^{1}$, Nam S.I. ${ }^{4}$, Kim J.-H. ${ }^{4}$ \\ ${ }^{1}$ Herzen State Pedagogical University of Russia, Nab. Moyki 48, St. Petersburg, 191186, Russia \\ ${ }^{2}$ Moscow State University, Vorobiovy Gory 1, Moscow, 119991, Russia \\ ${ }^{3}$ Institute of Geography RAS, Staromonetny lane 29, Moscow, 119107, Russia \\ ${ }^{4}$ Korean Polar Research Institute, Songdomirae-ro 26, Yeonsu-gu, Incheon 21990, South Korea
}

\begin{abstract}
We present the preliminary results of the granulometric and geochemical analyses of lakebottom sediments obtained from the Murmanskoe and Maloe Murmanskoe lakes. Based on the collected data, we reconstructed changes of relative sea-level (RSL) in the Gulf of Dvina (White Sea) during the Holocene. The conditions and maximum levels of two transgressions (Late Glacial and Tapes) and one Early Holocene regression were identified.
\end{abstract}

Keywords: lake sediments, Holocene, White Sea, sea-level change, grain-size, geochemistry

\section{Introduction}

The reconstruction of the relative sea-levels of the White Sea requires to identification glacioisostatic and eustatic components that determined the asynchronous formation of the coast during the Holocene. Therefore, different areas of the White Sea region need to be investigated, including the coast of the Gulf of Dvina. In addition to the previous stratigraphic (Peretrukhina et al., 2019), geochronological and diatom (Repkina et al., 2019) studies, we performed granulometric and geochemical analyses for sediment cores taken from the Murakanskoe and Maloe Murakanskoe lakes.

\section{Methods}

Fieldworks, lithological descriptions, and the radiocarbon and diatom data of the study area have been reported by Peretrukhina et al., (2019) and Repkina et al., (2019). In Lake Maloe Murakanskoe, a core was sampled in the western part of the lake with a maximum water depth 4 meters (core ID MM), at the foot of the moraine ridge (Peretrukhina et al., 2019). In Lake Murakanskoe, three drilling cores were sampled: two in the western and eastern parts of the lake (core ID MT2 and MT3, respectively) and one in the central part (not used for this study).

Grain-size and bulk geochemical analyses were conducted at the Korea Polar Research Institute (KOPRI) for reconstructing sedimentary environments

*Corresponding author.

E-mail address: yukublitskiy@herzen.spb.ru (Y.A. Kublitskiy) (freshwater or marine). The grain-size measurements of in total 107 samples (cores MM $(n=40)$, cores MT2 $(n=36)$, and MT3 $(n=31))$ were carried out for the range of 0.02 to $3000 \mu \mathrm{m}$ using a Malvern Mastersize laser particle sizer (Mastersizer 3000). The interpretation and the classification were based on Blott and Pye (2012).

The content of total organic carbon (TOC) and total nitrogen (TN) and their isotopes $\left(\delta^{13} \mathrm{C}_{\mathrm{TOC}}\right.$ and $\left.\delta^{15} \mathrm{~N}_{\mathrm{TN}}\right)$ of in total 84 samples (cores MM $(n=30)$, cores MT2 $(n=24)$ and MT3 $(n=30))$ were determined with a Flash 2000 organic elemental analyzer connected to a Delta V Plus isotope ratio mass spectrometer (Thermo Fisher Scientific).

\section{Results and Discussion}

Two investigated lakes are located near the coastal line of the White Sea in different hypsometrical levels. There are no salinity indicators in bottom sediments of Lake Maloe Murakanskoye $(10.9 \mathrm{~m}$ above sea level), also diatoms were not found in the MM core (Repkina et al., 2019). The existence of the straits between Lake Maloe Murmanskoe and the Gulf of Dvina can be tentatively associated with Late Glacial transgression $\sim 13.5$ to 11.5 cal. kyr BP (Kolka and Korsakova, 2017).

The first and rapid lithological changes in the core MM occurred at 10.4-10.1 cal. kyr BP (Repkina et al., 2019). This time interval corresponds to the 
beginning of the peat horizon formation above sands, that evidence about complete drainage of the basin. Characteristics of the early Holocene regression were also found in the core MT2 - age of the peat was 9.469.09 cal. kyr BP. It is most likely the RSL was below $7 \mathrm{~m}$ above sea-level at that time. The peat formation continued in the eastern basin of Lake Murakanskoe up to 8.55-8.39 cal. kyr BP (Repkina et al., 2019). Then, during the Tapes transgression, the RSL rose again.

Clayish gyttja began to accumulate above the peat; the interval of $525-507 \mathrm{~cm}$ in the core MT2 indicates an increase of salinity, $\delta^{13} \mathrm{C}_{\mathrm{TOC}}$ of $>-24 \%$, and $\mathrm{C} / \mathrm{N}$ ratio of $<9.5$. The intervals of $507-485 \mathrm{~cm}$ were probably related to the meromictic stage of the lake since there was a weak salinity signal along with the absence of freshwater indicators. Above 485 $\mathrm{cm}$, the sediments were represented by typical lake deposits with $\delta^{13} \mathrm{C}_{\text {тос }}$ of $<-24 \%$ and $\mathrm{C} / \mathrm{N}$ ratio of $>10$, which indicates the freshwater condition in the lake. Accordingly, our results provide valuable information for clarifying the history of RSL changes in the White Sea.

\section{Conclusions}

Late Glacial transgression in the Eastern part of Onega Peninsula was higher than $11 \mathrm{~m}$ above present sea level. The Early Holocene regression occurred earlier than 10.4-10.1 cal. kyr BP with the elevation $10.9 \mathrm{~m}$ above sea level and earlier than 9.46-9.09 cal. kyr BP with the elevation $7 \mathrm{~m}$ above sea level. In the beginning, the regression would have been rapid, but gradual at the final stage. The Mid Holocene transgression began to ca. 8.55-8.39 cal. kyr BP and its highest level did not exceed $10.9 \mathrm{~m}$ in the investigated area. In near future, we will provide new radiocarbon data for better estimating the RSL degreasing.

\section{Acknowledgments}

The implementation of grain-size and bulk geochemical analyses were realized by the KOPRI fellowship 2019 support. Fieldworks were carried out on the topic of GZ AAAA-A16-116032810089-5, in the framework of the agreement on the scientific cooperation No. 325 dated 17.05.2017 between NP "Kenozersky" and the faculty of the geography of Lomonosov Moscow State University. The data processing was supported by the RFBR project 19-05-00966 (geomorphological analysis), and the radiocarbon dating was conducted as a government task for the Department of the History of Geology RAS (GZ AAAA-A16-116032810055-0). The research was also supported by the Ministry of Education of the Russian Federation as part of a state task (project no. FSZN-2020-0016).

\section{References}

Blott S. J., Pye K. 2012. Particle size scales and classification of sediment types based on particle size distributions: review and recommended procedures. Sedimentology 59: 2071-2096.

Kolka V.V., Korsakova O.P. 2017. The position of the White Sea coastline and neotectonic movements in the NorthEast of Fennoscandia in the late Paleocene and Holocene. T. IV. Sedimentation processes, Geology and history. Moscow: Scientific World, pp. 222-249.

Peretrukhina A.A., Repkina T.Yu., Leont'ev P.A. et al. 2019. Study of bottom sediments Murakanskoe and Maloe Murakanskoe lakes of the Onega Peninsula of the White Sea. The first results. Collective monograph on the materials of the annual all-Russian with international participation scientific and practical conference LXXII Herzen readings, vol. 1. Publishing house of the Herzen state pedagogical University. A. I. Herzen, St. Petersburg, pp. 381-385.

Repkina T. Yu., Kublitsky Yu. A., Leontiev P. A. et al. 2019. Lakes of the Letniy coastal line of the White Sea: mechanisms and chronology of isolation. Collective monograph on the materials of the annual all-Russian with international participation scientific and practical conference LXXII Herzen readings, vol. 1, publishing house of the Herzen state pedagogical University. A. I. Herzen, St. Petersburg, pp. 337-341. 